\title{
Editorial
}

\section{Islam and Pluralism}

Is religious pluralism possible in Islam? This question is theoretically and historically easy to answer affirmatively. But in perception seen as reality, it is anything but simple to answer at all. Contemporary attitudes toward and portrayals of Muslims confuse the debate even further. Attempts to provide legitimate answers in a nuanced manner are usually considered apologetics and thus dismissed. Yet the case must be made that the Islamic worldview on religion and humanity assumes religious pluralism.

Anybody periodically engaged in interfaith dialogue or public lectures on Islam must have heard this question by now. While most are genuinely interested in knowing the true answer, some have already made their minds up about Islam's inability to tolerate other religions. Perhaps one of the effective answers came through Bill Moyers' 1990 interview with Seyyed Hossein Nasr. ${ }^{1}$ That Nasr answered affirmatively with authority and eloquence cannot be denied; however, that few Americans heard his answer is confirmed by the persistence of this question twenty years later. Significantly, that even fewer would have believed him is proven by the troublesome rhetoric of the current rising Islamophobia.

Moyers's questions included the following: "By the nature of its theology, its own principle of unity, ... can Islam coexist with [a] non-Muslim [world]?"; "Do Muslims envision a world dominated by Islam?”; “One does not see pluralism and tolerance?"; "Can you [Muslims] tolerate [an] infidel?"2 Nasr responded by affirming coexistence, pluralism, and tolerance and rejecting any notion of Muslim world domination. This editorial analyzes "Islam and pluralism." But to understand the Muslims' response, one must accept some basic facts: Muslim extremists, who have always existed, do not truly and legitimately represent Islam by their actions or pronouncements. Obvi- 
ously they are part of the Muslim world, but in numerical terms they remain a negligible minority. Moreover, Muslims are not a monolithic group; rather, they represent many constituents, the majority of which are peaceful and tolerant and aspire to live with others in a secure world. ${ }^{3}$

\section{Pluralism in a Muslim-majority Nation}

The archetype of a Muslim-majority was that of Madinah from $622 \mathrm{CE}$ onward. Although Muslims ever since may have wished or even fantasized about a Muslim-only world, there has never been (nor is there) a realistic expectation for that. Some Islamic eschatological narrations predict that "belief in God" will reign supreme before the end of time, but this is far from suggesting that everybody will become Muslim. The Qur'an has always implied that multiplicity of religious communities and, therefore, pluralism are necessary for God to test their commitment to obeying Him and doing good deeds in accordance to their respective books. "If God had so willed, He would have made you [humanity] one community, but $\mathrm{He}$ wanted to test you through that which He has given you [i.e. "books"; according to al-Tabari] so race to do good: you will all return to God and He will make clear to you the matters you differed about" $(5: 48){ }^{4}$ So diversity of religions is expected and pluralism is anticipated.

On the practical level, pluralism signifies different communities of people living peacefully and amicably in one geographical and territorial setting. Muslims, as a matter of attaining peace, must first strive toward pluralism. This is what the Prophet did in Madinah, which had a substantial Jewish population. Among the first things he did was to get all of Madinah's inhabitants to agree to the conditions laid out in the "Constitution of Madinah." Al-Zuhri (d. 742), Ibn Ishaq (d. 767), Ibn Hisham, Ibn Kathir (d. 1373), and other historiographers left a detailed record of this document; Julius Wellhausen, Arent J. Wensinck, W. Montgomery Watt, Robert B. Serjeant, Uri Ruben, Frederick M. Denny, and other leading western scholars have analyzed it. The ummah, in this case the inhabitants of Madinah and their allies, is of crucial importance to understanding Islam's position to pluralism.

With respect to this discussion, scholars have identified articles 1, 25, 37, 39, and 40 as relevant. ${ }^{5}$ The document begins by proclaiming: "In the name of God, the Merciful, the Compassionate. This is a writing of Muhammad the Prophet between the believers and Muslims of Quraysh and Yathrib and those who follow them and are attached to them who strive/ fight (jahadu) along with them." This is followed by the articles: 
1. They are one community (ummah wahidah) distinct from other people.

25. The Jews of Banu Awf are a community (ummah) along with the believers. To the Jews their religion ( din) and to the Muslims their religion, both to their clients and to themselves, with the exception of anyone who has done wrong or acted treacherously; he brings evil only on himself and on his household.

37. Between them, there is help (nasr) against whoever wars against the people of this document. Between them is sincere friendship and counseling, and honorable dealing, not treachery.

39. The valley of Yathrib is sacred and protected for the people of this document.

40. The neighbor is as the man himself so long as he does no harm and does not act treacherously. ${ }^{6}$

Other articles talk of how no one must help the Makkans or take them as allies against the signatories to this document. Although Muslims and many leading western scholars on Islam consider this document a blueprint for pluralism, people still read in it anti-Jewish sentiment (e.g., reading dayn [debt] for din [religion] in article 25), insist that the signatories are somehow unequal, or focus on the ultimate elimination of some Jews who were believed to have conspired to kill the Prophet and therefore broken it. Other people still challenge its very authenticity. But why the Prophet to have drawn up this document if he had no intention of instituting or honoring its clauses? History shows that not only did he honor it, but that he moved against only those Jewish clans accused of violating it - not against those Jews who continued to honor it. Practicing Muslims attempt to emulate the Prophet's actions in all of their activities and as closely as they can.

Rubin writes:

The conclusion with respect to article one of the "Constitution" is, therefore, inevitable. The article declares that the Muslims of Quraysh and Yathrib, as well as the Jews, constitute one unity, sharing the same religious orientation, thus being distinct from all the rest of the people who adhere to other kinds of faith. It is thereby clear that the new unity is designed to be based not only on common sacred territory but also on common faith. ${ }^{7}$

The fact that this experiment may be portrayed as a failure due to Muhammad's ultimate expulsion and killing of some Jews who plotted to kill him may have temporarily vitiated, Islam's basic position toward plu- 
ralism has never been altered. This is especially telling when Muslims were convinced that some of the Jewish tribes violated agreements for pluralism and thus jeopardized the Prophet's life. When reading this constitution, one feels that this "failure" might have been exaggerated. Despite the unfortunate outcome, various Jewish communities continued to live with Muslims as part of one community, as delineated by the constitution. When the Prophet died, he owed a Jewish neighbor some money. People must live together in one location to be neighbors. Neighbors must trust each other in order to conduct social and commercial transactions. Neighbors must be comfortable with each other in order to lend money. If all this was true to the Prophet and his Jewish neighbors, what can stop it from occurring among the larger community of Madinah? Significantly, how can this prove that Islam is against pluralism?

In pluralistic societies, the equality of different peoples is a legitimate question. But while failure to achieve equality is a serious setback, it must not be used to paint a picture contrary to pluralism. This is true whether the pluralism is based on ethnic, political, or religious factors. With majority comes the opportunity to dictate, influence, and control situations. And as long as other groups are free to act as they choose (in this case religiously) without persecution or hindrance, pluralism is achieved.

In Islam's case, the practical application of pluralism over time has a mixed record. Many caliphs and sultans allowed non-Muslims to live and practice their religions freely, even making space for them to partake in the social, intellectual, and political arenas; others restricted their movement and ordered them to wear special attire. But the overwhelming evidence supports the fact that non-Muslims who lived under Islamic rule fared relatively better treatment than those who lived under non-Islamic rule.

The discussion of the People of the Book (ahl al-kitab) and protected people (ahl al-dhimmah) in Islamic jurisprudential literature may be interpreted, and usually perceived, as portraying non-Muslims as second-class citizens. It is unclear how people belonging to non-Abrahamic religious traditions should be treated. In truth, all these medieval constructions of rules were based on the bifurcation of the world into dar al-Islam and dar al-harb. There were, however, other classifications, such as dar al- 'adl (the abode of justice, where Muslims are minority but given their rights) and dar al- 'ahd (the abode of covenant, where the minority Muslims have signed a peace treaty).

In the case of the United States, religious pluralism did not come via the teachings and practices of religious (Christian) institutions. In the sixteenth and seventeenth centuries, different religious groups were persecuted for 
their beliefs and practices (i.e., the Pueblo Nation under the Franciscan Friars in New Mexico, Anne Hutchinson under the Puritan Congregational Church in Massachusetts, and the Baptists under the Protestants in the south). Religious pluralism came through political initiatives that guaranteed the freedom of religions. ${ }^{8}$

As I mentioned earlier, imperfection should not be used to deny the existence of pluralism. It is well-known that there is intolerance in America's religious sphere. Due to the discrimination, outright Islamophobia, and other negative realities faced by Muslims in this country today, many of them find it hard to accept that religious pluralism still exists here; however, many Americans remain willing to stand with them.

Non-Muslims who face discrimination in Muslim-majority nations also find it hard to accept Islam's asserted religious tolerance. Clearly, Muslimmajority nations need to implement more guarantees for non-Muslims as a matter of religious obligation, political expedience, and human rights. Sadly, even non-religious Muslim leaders may violate the religious rights of nonMuslims to bolster their political standing among their Muslim constituents, as if persecuting other religions is somehow "Islamic." Yet, the majority of Muslims understand that living peacefully with non-Muslims is "Islamic" and they have been doing so for centuries.

Hopefully Muslims will remember that the Islamic worldview not only implies religious pluralism, but that the Prophet's sunnah actively encourages it. In fact, he was ready to do anything short of sacrificing his life to achieve this goal. AJISS would welcome any academic papers addressing the practical aspects of "Islam and pluralism" among Muslim-majority peoples in different geographical areas and historical time periods.

This issue of AJISS opens with Mazen Hashem's “Asserting Religious Text in the Modern World: Muslim Friday Khutbahs." As a trained sociologist, Hashem's keen interest in Muslims in this country led him to analyze two year's worth of khutbahs. He focuses on three dimensions: how certain texts assert their authority, the different approaches to contextualizing the texts, and how texts are interpreted in the face of modern challenges. Ruzita Mohd. Amin follows with her "A Decade of the World Trade Organization and the Trade Performance of Muslim Countries." In her analysis of the performance of the merchandise trade of Muslim countries after they joined the WTO, she describes their participation in world merchandise trade, highlights their trade characteristics in general, and discusses the implications of WTO agreements on Muslim countries. She closes with some recommendations related to facing this challenge. 
The next paper, Sayed Sikandar Shah and Mek Wok Mahmud's "Critical Thinking and Its Implications for Contemporary Ijtihad," briefly delineates the concept of critical thinking and its dynamic role in reconstructing human thought. They also relate the on-the-ground realities regarding recent Islamic revival movements and their zeal for reinstituting this process. Finally, they identify some hands-on strategies for applying critical thinking in contemporary ijtihad. We close with Sobhi Rayan's "Ibn Taymiyya's Criticism of Aristotelian Definition." Rayan tackles Ibn Taymiyya's efforts to criticize Aristotle's two "points of definition": one posited in negative terms and the other in positive terms. He concludes that while Ibn Taymiyya's main criticism is directed at specific metaphysical elements of definition, such as genus, species, differences, quiddity, and universality, he also argues that these elements are purely mental and do not necessarily correspond to existence.

We hope that we have, once again, assembled a collection of thoughtprovoking articles for our readers and believe they will be stimulated by the variety of approaches and ideas posited in them.

\section{Endnotes}

1. "Bill Moyers Rewind: Seyyed Hossein Nasr on Finding Peace in the Middle East (1990)," www.pbs.org/moyers/journal/blog/2008/02/bill_moyers_ rewind_seyyed_hoss.html.

2. Ibid.

3. For more, see John L. Esposito and Dalia Mogahed, Who Speaks for Islam?: What a Billion Muslims Really Think (New York: Gallup Press, 2008).

4. Other verses include 11:118 and 42:8; also see, al-Tabari, Jami 'al-Bayan 'an Ta'wil ay al-Qur'an, 10:390-91.

5. Frederick M. Denny, "Ummah in the Constitution of Medina," Journal of Near Eastern Studies 36, no. 1 (1977): 42.

6. Ibn Hisham, Al-Sirat al-Nabawiyah (Beirut: Dar al-Kitab al-Arabi, 2006), 1:299-300. Denny's translation with a few modifications, pp. 40-42.

7. Uri Rubin, “The 'Constitution of Medina': Some Notes," Studia Islamica 62 (1985): 13.

8. "God in America" TV Program: KLCS on PBS, 8:00-10:00 pm, 4 December 2010.

Zakyi Ibrahim

Editor

zibrahim@fullerton.edu 